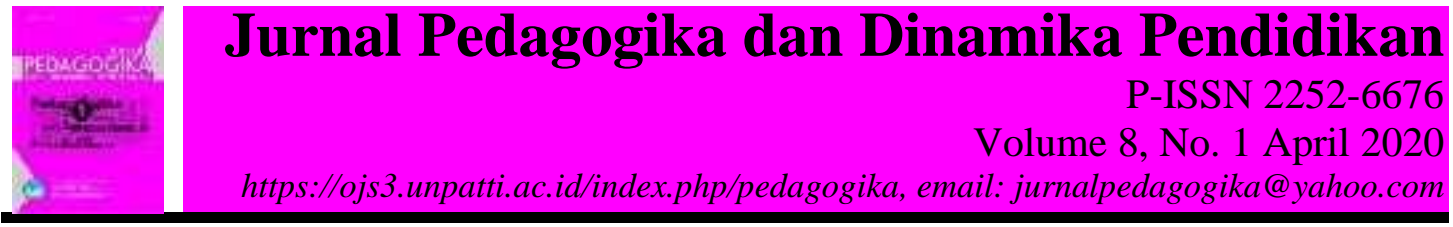

\title{
PENINGKATAN PEMAHAMAN ISI CERPEN MENGGUNAKAN MODEL PEMBELAJARAN WORD SQUARE PADA SISWA KELAS IV SD NEGERI 69 AMBON
}

\author{
Sarah Sahetapy ${ }^{1}$, Zainab Rery ${ }^{2}$, Anggar Purwanti Idris ${ }^{3}$, \\ ${ }^{1,2}$ Dosen Program Studi PGSD FKIP Univeritas Pattimura Ambon \\ ${ }^{3}$ Mahasiswa Program Studi PGSD FKIP Univeritas Pattimura Ambon \\ Email: sarahsahetapy10@gmail.com
}

\section{ARTICLE INFO}

Article History:

Accepted 28 Maret 2020

Available Online 15 April 2020

Keywords:

Peningkatan

Pemahaman,

Cerpen, Model Pembelajaran,

Word Square

\begin{abstract}
Tujuan Penelitian ini adalah meningkatkan pemahaman isi cerpen dengan menggunakan model pembelajaran Word Square. Model pembelajaran Word Square dipakai untuk mengatasi ketidakmampuan siswa dalam memahasi isi cerita. Metode penelitian yang digunakan dalam penelitian ini adalah penelitian tindakan kelas dengan subjek penelitian, siswa kelas IV SD Negeri 69 Ambon yang berjumlah 23 siswa. Subjek ditentukan setelah dilakukan tes awal dan terpilih 9 siswa, dengan perincian 3 siswa dari kelompok tinggi, 3 siswa dari kelompok sedang, dan 3 siswa dari kelompok rendah. Teknik pengumpulan data yang dilakukan pada penelitian ini adalah teknik tes, non tes, observasi, dokumentasi dan data hasil belajar.

Hasil penelitian menunjukkan bahwa model pembelajaran Word Square dapat meningkatkan kemampuan memahami isi cerpen pada siswa kelas IV SD Negeri 69 Ambon. Berdasarkan hasil tes setiap siklus, yaitu pada siklus I siswa memperoleh kriteria ketuntasan minimal (KKM) $\geq 65$ sebanyak 5 siswa dengan presentase sebanyak $74 \%$ sedangkan pada siklus II meningkat $81,90 \%$, yaitu menjadi $100 \%$ dengan jumlah siswa yang memperoleh nilai $\geq 65$ sebanyak 9 siswa.
\end{abstract}




\section{PENDAHULUAN}

Cerita pendek merupakan salah satu bentuk karya fiksi yang sifatnya serba pendek baik dari segi peristiwa yang diceritakan, isi cerita, maupun jumlah pelaku dan jumlah kata tetapi mengandung kesan yang sangat dalam. Menurut Priyatni (2010: 126), cerita pendek memiliki beberapa unsur yaitu : a)tema b) tokoh c) alur atau plot d) setting atau latar, dan e) amanat.

Dalam sebuah cerita pendek, ada banyak hal yang harus dipahami oleh siswa mengenai cerita yang dibaca diantaranya tentang tokoh yang ada dalam cerita, karakteristik tokoh, dan makna dari cerita tersebut. Hasil akhir dari berbagai rangkaian pemahaman siswa tersebut adalah siswa diharapkan mampu mengungkapkan kembali isi cerita atau meringkas isi cerita. Semua hal itu tidaklah terlepas dari kemampuan siswa dalam memahami isi cerita. Ada pun beberapa penyebab masih rendahnya kemampuan siswa dalam memahami isi cerita pendek, yaitu (1) metode yang digunakan guru kurang menarik sehingga siswa cepat bosan, (2) pembelajaran masih berpusat pada guru, (3) pembelajaran masih bersifat pasif learning sehingga siswanya juga menjadi pasif dan menyebabkan motivasi siswa menurun (Jampar, 2015:343-344).

Permasalahan tersebut juga terjadi pada siswa kelas IV SD Negeri 69 Ambon. Hal ini diketahui setelah dilakukan Observasi dan wawancara di SD Negeri 69 Ambon. Kelemahan siswa yang paling utama terletak pada kurang mampu mengembangkan isi cerita, kebanyakan mereka mengulang-ulang kata atau kalimat yang sama. Guru menerangkan bahwa siswa memang masih sangat sulit untuk mengungkapkan kembali isi cerita dan tingkat pemahaman siswa terhadap isi cerita masih rendah. Pembelajaran keterampilan menulis khususnya cerita pendek masih kurang maksimal ini coba diatasi dengan menerapkan model pembelajaran yang membuat siswa mengembangkan pemikiran dan daya nalar mereka. Model pembelajaran yang digunakan yaitu Model Pembelajaran Word Square.

Word Square berasal dari kata word yang artinya kata dan square yang artinya persegi. Word Square merupakan model yang memadukan kemampuan menjawab pertanyaan dengan kejelian dalam mencocokan jawaban pada kotak-kotak jawaban hampir sama dengan teka teki silang tetapi bedanya jawabannya sudah ada, namun disamarkan dengan menambahkan kotak tambahan dengan sembarang huruf atau angka penyamar atau pengecoh (Trianto 2011:23). Model Word Square merupakan pembelajaran kooperatif yang menuntut kemandirian peserta didik dalam menemukan kata-kata dalam kotak kata. Menggunakan model pembelajaran ini di kelas akan mengurangi ketergantungan siswa terhadap guru sehingga pembelajaran tidak hanya berpusat dari guru. Sehingga dalam proses pembelajaran daam kelas menjadi lebih efektif dan menyenangkan.

Dari definisi di atas, dapat disimpulkan bahwa model pembelajaran Word Square ialah model pembelajaran yang didalamnya berisi permainan acak akata huruf menjadi kata dalam satu bingkai kotak, dimana siswa diminta untuk menghubungkan huruf dengan cepat dan baik secara mendatar maupun menurun. Aktivitas mencari kata membantu siswa mengendapkan materi ajar yang telah dipelajarinya. Fokus aktivitas mencari kata seperti "tokoh utama" kembali pengetahuan materi ajar. Menggunakan model pembelajaran ini akan membantu peserta didik mengingat kembali kata-kata pengetahuan dari materi yang telah dipelajari sebelumnya.

Dalam proses pembelajaran, peserta didik berupaya mengingat kembali memori pengetahuan, proses mengingat dalam mencari kata akan menyebabkan informasi pengetahuan semakin tersimpan kuat pada bagian neokorteks otak. Aktivitas ini menyebabkan informasi pengetahuan tersimpan dalam memori jangka panjang. Hal ini 
memungkinkan menjadi salah satu keuntungan bagi peserta didik dalam pembelajaran Bahasa Indonesia pada tingkat selanjutnya.

Model ini secara teknis adalah kegiatan belajar mengajar dengan cara pendidik membagikan lembar kegiatan atau lembar kerja sebagai alat untuk mengukur tingkat pemahaman peserta didik terhadap materi pelajaran yang telah diajarkan. Adapun instrumen utama model ini adalah lembar kegiatan atau kerja berupa pertanyaan atau kalimat yang perlu dicari jawabannya pada susunan huruf acak pada kolom yang telah disediakan. Dibawah ini adalah contoh dari Word Square yaitu sebagai berikut:

Tabel 1.1 Contoh Word Square

\begin{tabular}{|l|l|l|l|l|l|l|}
\hline A & c & j & a & A & n & i \\
\hline J & t & u & p & K & r & a \\
\hline F & h & d & a & a & a & b \\
\hline I & b & u & l & v & y & b \\
\hline Y & y & l & a & t & a & r \\
\hline A & a & k & t & a & h & u \\
\hline N & u & p & i & a & j & y \\
\hline
\end{tabular}

(Sumber: Tukiran, Dkk: 2015, h.115)

Langkah-langkah Model Pembelajaran Word Square antara lain sebagai berikut (Aqib, 2013:31):

a) Guru menanyakan materi sebelumnya dan menjelaskan materi selanjutnya secara singkat.

b) Guru menyiapkan kotak atau matriks.

c) Guru dan siswa melakukan tanya jawab tentang materi yang telah dijelaskan.

d) Guru meminta peserta didik maju ke depan untuk menarsir jawaban yang ada di dalam kotak.

e) Guru membagikan lembar kerja dengan jawaban yang diacak susunannya.

f) Peserta didik menjawab pertanyaan-pertanyaan yang diberikan guru.

g) Guru melakukan evaluasi.

Sementara itu, Kurniasih (2016: 98) menguraikan kelebihan pembelajaran kooperatif tipe Word Square antara lain:

a) Word Square cenderung menggali pengetahuan siswa dalam pembelajaran, karena Word Square berupa permainan kotak kata yang berisi kumpulan huruf .

b) Penggunaan Word Square lebih mudah dipahami dan diingat oleh siswa yang akan menegaskan pemahaman materi siswa.

c) Membantu siswa membiasakan diri membaca buku pelajaran, karena Word Square memerlukan pengetahuan dsar dari siswa.

d) Siswa dapat berlatih kreatif dan terampil belajar mandiri dalam membuat pertanyaan dan memanfaatkan buku sumber.

e) Dapat melatih sikap teliti dan kritis.

f) Merangsang siswa untuk berpikir efektif 
Kekurangannya juga diungkapkan Kurniasih (2016:98), antara lain:

a) Metode pembelajaran seperti ini biasanya menimbulkan suatu kegaduhan, hal tersebut jelas akan mengganggu kelas yang berdekatan.

b) Siswa tidak dapat mengembangkan materi yang ada dengan kemampuan atau potensi yang dimilikinya.

c) Dalam model pembelajaran ini, siswa tidak dapat mengembangkan kreativitas masingmasing, dan lebih banyak berpusat oleh guru.

Model pembelajaran Word Square dapat menjadikan peserta didik aktif dalam proses pembelajaran, dapat meningkatkan hasil belajar dan dapat mengembangkan rasa saling bekerja sama antar peserta didik. Namun demikian ada kemungkinan peserta didik yang hanya menerima materi dari pendidik maka akan mengakibatkan peserta didik tidak dapat mengembangkan potensi yang dimilikinya dan pembelajaran hanya berpusat pada guru.

Sesuai dengan tujuan penelitian ini adalah penerapan model pembelajaran Word Square dalam meningkatkan pemahaman isi cerpen, maka berikut adalah langkahlangkahnya:

a) Guru memberikan apersepsi dengan bertanya jawaban terkait materi yang akan disampaikan yakni materi menulis cerpen.

b) Guru memberika motivasi dan meraih minatsiswa dengan membacakan cerita, memperlihatkan gambar atau video terkait menulis cerpen.

c) Guru menyampaikan tujuan pembelajaranyang akan dicapai.

d) Guru menyampaikan materi yakni materi menulis cerpen.

e) Memberi kesempatan bagi siswa untuk menulis cerpen.

f) Guru memandu dan membimbing siswa dalam menulis cerpen.

g) Mengumpulkan hasil kerja siswa.

h) Guru menyiapkan lembar kerja siswa sesuai hasil kerja siswa yang sebelumnya.

i) siswa ditugaskan menjawab soal-soal yang di berikan dengan mencari jawabannya di dalam LKPD yang telah disediakan.

j) Guru menyampaikan cara menyelesaikan LKPD.

k) Siswa diberi waktu menyelesaikan tugas yang diberikan.

1) Guru memberikan evaluasi.

\section{METODOLOGI}

Penelitian ini menerapkan metode Penelitian Tindakan Kelas (PTK). Wiriaatmadja (2009: 13) mengemukakan bahwa penelitian tindakan kelas adalah bagaimana sekelompok guru dapat mengorganisasikan kondisi praktik pembelajaran mereka, dan belajar dari pengalaman mereka sendiri. Penelitian tindakan kelas merupakan suatu pencermatan terhadap kegiatan yang sengaja dimunculkan, dan terjadi dalam sebuah kelas (Arikunto, 2006: 91).

Penelitian ini dilaksanakan di SD Negeri 69 Ambon. Subjek dalam penelitian ini adalah siswa kelas IV SD Negeri 69 Ambon yang berjumlah 23 siswa. Subjek akan ditentukan setelah dilakukan tes awal sehingga melalui tes awal akan diambil 9 siswa sebagai subjek, dengan perincian 3 siswa dari kelompok tinggi, 3 siswa dari kelompok sedang, dan 3 siswa dari kelompok rendah. Teknik pengumpulan data yang dilakukan pada penelitian ini adalah teknik tes, non tes, observsi, dokumentasi dan data hasil belajar.

Teknik analisis data yang dilakukan pada penelitian ini yaitu secara kuantitatif. Menurut Suharsimi Arikunto (2010: 282), apabila data telah terkumpul, lalu diklasifikasikan menjadi dua kelompok data, yaitu data kuantitatif yang berbentuk angka-angka. Data yang diperoleh dalam penelitian ini adalah nilai cerita pendek siswa. Data nilai cerita pendek siswa 
dianalisis menggunakan kuantitatif yaitu mencari nilai rata-rata cerita pendek. Rumus yang digunakan untuk mencari nilai rata-rata menurut Anas Sudijono (2010: 81) adalah sebagai berikut.

$$
\begin{aligned}
& \mathrm{Mx}=\frac{\Sigma x}{N} \\
& \text { Keterangan: } \\
& \text { Mx = Mean (rata-rata) } \\
& \text { = Jumlah skor } \\
& \mathrm{N}=\text { Jumlah siswa. }
\end{aligned}
$$

Sedangkan untuk menghitung presentase ketuntasan belajar klasikal data tersebut diolah dengan menggunakan rumus presentase menurut Anas Sudijono (2010: 43) adalah sebagai berikut :

$$
\mathrm{P}=\frac{r}{N} \times 100 \%
$$

\section{Keterangan:}

$$
\begin{aligned}
& \mathrm{P}=\text { Angka presentasenya } \\
& \mathrm{F}=\text { Frekuensi yang sedang dicari presentasenya } \\
& \mathrm{N}=\text { jumlah frekuensi/banyak individu }
\end{aligned}
$$

Tabel 2.1 Acuan Konversi Penelitian

\begin{tabular}{|c|c|}
\hline Nilai & Keterangan \\
\hline $80-100$ & Sangat Baik \\
\hline $66-79$ & Baik \\
\hline $56-65$ & Cukup \\
\hline $40-55$ & Kurang \\
\hline $30-39$ & Sangat Kurang \\
\hline
\end{tabular}

(Arikunto, 2006: 245)

\section{HASIL DAN PEMBAHASAN}

Penelitian ini dibagi menjadi dua siklus yaitu siklus I dan siklus II. Setiap siklus terdiri atas satu pertemuan dan setiap pertemuan pembelajaran berlangsung selama 2x35 menit. Setiap pembelajaran dilakukan melalui empat tahap yaitu perencanaan, tindakan, observasi, dan refleksi. Sebelum melakukan penelitian, peneliti melakukan tes awal terlebih dahulu untuk siswa kelas IV dengan tujuan untuk dapat menentukan subjek penelitian yang terdiri dari 9 orang siswa.

\section{a. Hasil Tes Awal}

Tahapan ini merupakan gambaran awal dari siswa sebelum tindakan dilaksanakan oleh peneliti. Kondisi awal siswa diperoleh dari hasil rata-rata nilai siswa dalam memahami isi cerpen. Untuk memperoleh hasil tersebut, peneliti melakukan tes awal kemudian hasil tes yang dilakukan sehingga siswa kesulitan dalam memahami isi cerpen. Berikut ni hasil tes 
awal pada 23 siswa kelas IV SD Negeri 69 Ambon. Oleh peneliti dengan 25 siswa kelas IV maka diperoleh hasil rata-rata kempuan siswa dalam memahami isi cerpen adalah $36 \%$. Hal itu menunjukan bahwa kemampuan rata-rata kelas tersebut termasuk dalam kategori kurang danbelum mampu mencapai kriteria ketuntasan klasikal yang ditentukan yaitu 80\%, masih banyak siswa di bawah KKM yang ditentukn sekolah $\geq 65$.

Tabel 3.1 Hasil tes awal pemahaman isi cerpen

\begin{tabular}{|c|c|c|c|c|c|c|c|}
\hline \multirow{3}{*}{ No } & \multirow{3}{*}{$\begin{array}{l}\text { Inisial } \\
\text { Siswa }\end{array}$} & \multicolumn{4}{|c|}{ Aspek Yang Dinilai } & \multirow{3}{*}{$\begin{array}{l}\text { Nilai } \\
\text { Akhir }\end{array}$} & \multirow{3}{*}{ Keterangan } \\
\hline & & $\begin{array}{c}\text { Mengamati } \\
\text { Gambar Cerpen }\end{array}$ & $\begin{array}{c}\text { Menentukan } \\
\text { Tema }\end{array}$ & $\begin{array}{c}\text { Menentukan } \\
\text { Tokoh }\end{array}$ & $\begin{array}{c}\text { Menentukan } \\
\text { Alur }\end{array}$ & & \\
\hline & & $0-20$ & $0-30$ & $0-20$ & $0-30$ & & \\
\hline 1 & M.R.S & 15 & 20 & 19 & 20 & 76 & Baik \\
\hline 2 & R.B.R & 14 & 22 & 18 & 22 & 74 & Baik \\
\hline 3 & A.V.W & 13 & 21 & 17 & 21 & 70 & Baik \\
\hline 4 & M.A & 12 & 24 & 16 & 24 & 70 & Baik \\
\hline 5 & D.A.S & 11 & 20 & 15 & 20 & 69 & Cukup \\
\hline 6 & H.F & 12 & 18 & 14 & 18 & 68 & Cukup \\
\hline 7 & S.F.M & 20 & 10 & 13 & 10 & 66 & Cukup \\
\hline 8 & I.L.S & 20 & 15 & 12 & 15 & 66 & Cukup \\
\hline 9 & C.I & 19 & 12 & 10 & 12 & 65 & Cukup \\
\hline 10 & M.S & 18 & 11 & 11 & 11 & 64 & Cukup \\
\hline 11 & S.D.M & 17 & 10 & 15 & 10 & 64 & Cukup \\
\hline 12 & D.R & 16 & 12 & 14 & 12 & 63 & Cukup \\
\hline 13 & A.W & 15 & 13 & 15 & 13 & 63 & Cukup \\
\hline 14 & S.N & 14 & 11 & 16 & 11 & 62 & Cukup \\
\hline 15 & L.H & 13 & 12 & 17 & 12 & 62 & Cukup \\
\hline 16 & N.S & 10 & 25 & 12 & 13 & 60 & Cukup \\
\hline 17 & W.L & 10 & 13 & 12 & 25 & 60 & Cukup \\
\hline 18 & A.H.M & 9 & 12 & 13 & 25 & 58 & Cukup \\
\hline 19 & M.F.R & 9 & 19 & 12 & 18 & 56 & Cukup \\
\hline 20 & L.A.L & 9 & 18 & 9 & 20 & 50 & Kurang \\
\hline 21 & M.I.D & 6 & 15 & 9 & 20 & 42 & Kurang \\
\hline 22 & A.L & 6 & 9 & 10 & 15 & 40 & Kurang \\
\hline 23 & H.H & 3 & 10 & 7 & 15 & 35 & $\begin{array}{c}\text { Sangat } \\
\text { Kurang }\end{array}$ \\
\hline & & & Rata-rata & & & 61 & $\begin{array}{l}\text { Belum } \\
\text { Tuntas }\end{array}$ \\
\hline
\end{tabular}

Berdasarkan tabel 3 diatas, dapat diketahui bahwa sebelum mendapat tindakan sebanyak 4 siswa atau 17\% memiliki kemampuan memahami isi cerpen dalam kategori baik, dan sebanyak 15 siswa atau $66 \%$ memiliki kemampuan memahami isi cerpen dan sebanyak 4 siswa atau $17 \%$ memiliki kemampuan memahami isi cerpen dalam kategori kurang. Ratarata nilai siswa dalam memahami isi cerpen adalah $61 \%$. Dari hasil tes awal yang dilakukan, 
maka peneliti mengambil 9 orang siswa sebagai subjek pada penelitian ini, yaitu 3 siswa dalam kelompok yang nilainya tinggi/sangat baik, 3 siswa dari kelompok yang nilainya sedang/ baik, dan 3 siswa dari kelompok yang nilainya rendah/cukup.

\section{b. Hasil Penelitian Siklus I Dan Siklus II}

Pembelajaran memahami isi cerpen dengan menggunakan model pembelejaran Word Square ini pada hasil penelitian siklus I dan siklus II ini akan membahas mengenai proses pembelajaran, hasil tes, dan hasil nontes. proses pembelajaran memahami isi cerpen merupakan pemahaman siswa terhadap tema, alur, latar dan tokoh dalam cerita dan penerapan model pembelajaran Word Square di dalam kelas. mengenai hasil tes merupakan penejelasan hasil siswa mengerjakan tugas yang diberikan oleh guru sebagai penilaian. untuk hasil nontes akan dijabarkan dalam instrument berupa wawancara, observasi dan dokumentasi foto selama pembelajaran berlangsung. Semuanya berada pada lampiran/dokumentasi.

1. Tahap Perencanaan.

Dalam perencanaan pada siklus I dan 2, hal-hal yang disiapkan sebelum penelitian berlangsung yaitu:

a. Perangkat pembelajaran yang disiapkan yaitu, silabus, rencana pelaksanaan pembelajaran dan LKS (Individu).

b. Menyiapkan lembar observasi. Lembar observasi yang disiapkan yaitu, lembar observasi aktivitas guru dan lembar observasi aktivitas siswa.

c. Menyiapkan soal tes siklus I.

d. Penetapan kriteria penilaian, siswa dikatakan berhasil jika siswa tersebut mencapai nilai $\mathrm{KKM}$ yaitu $\geq 65$

2. Tahap Pelaksanaan

Pelaksanaan pembelajaran memahami isi cerpen pada siklus I pertemuan 1 dilaksanakan pada hari Senin, 7 oktober 2019 dengan pelaksaan pembelajaran sebagai berikut:

a. Kegiatan Awal :

Pada kegiatan awal, guru mengucapkan salam, guru memotivasi siswa utuk memulai proses pembelajaran, guru melakukan kegiatan apresepsi. Hal ini bertujuan untuk membangkitkan minat dan keingintahuan siswa terhadap materi yang akan diajarkan. selanjutnya agar guru menyampaikan tujuan pembelajaran.

b. Kegiatan inti :

Pada kegiatan inti, Guru menjelaskan apa itu cerita pendek, Siswa mendengarkan cerita pedek, Guru menjelaskan unsur-unsur intristik cerita pendek, Siswa mengamati gambar pada cerita, Siswa menentukan tema, tokoh dan alur cerita dengan mengutip kalimat atau paragraf yang mendukung melalui kegiatan penugasan menggunakan model pembelajaran Word Square, Guru menjelaskan cara menyelesaikan LKS, Siswa menentukan amanat yang terkandung dalam cerita.

c. Kegiatan Akhir

Pada kegiatan akhir, guru dan siswa sama-sama menyimpulkan materi pembelajaran, guru membuat evaluasi kerja, guru mengakhiri pembelajaran dengan berdoa, guru mengucapkan salam.

3. Observasi

Pada saat proses pembelajaran berlangsung, peneliti mengamati guru yang sedang mengajar, dan 5 observer mengamati semua siswa yang sedang 
memperhatikan guru mengajar dan menyelesaikan LKS. berikut ini hasil observasi dalam pembelejaran memahami isi cerpen melalui model pembelajaran Word Square.

a. Hasil Observasi Guru

Pada kegiatan awal, 1) Guru mengucapkan salam, 2) Guru memotivasi siswa untuk memulai proses pembelajaran, 3) Guru melakukan kegiatan apresepsi, 4) Guru menyampaikan tujuan pembelajaran.

Pada kegiatan inti, 1) Guru menjelaskan apa itu cerita pendek, 2) Siswa mendengarkan cerita pedek, 3) Guru menjelaskan unsur-unsur intristik cerita pendek, 4) Siswa mengamati gambar pada cerita, 5) Siswa menentukan tema, Tokoh dan alur cerita dengan mengutip kalimat atau paragraf yang mendukung melalui kegiatan penugasan menggunakan model pembelajaran Word Square, 6) Guru menjelaskan cara menyelesaikan LKS, 7) Siswa menentukan amanat yang terkandung dalam cerita.

Pada kegiatan akhir, 1) Guru dan siswa sama-sama menyimpulkan materi pembelajaran, 2) Guru membuat evaluasi kerja, 3) Guru mengakhiri pembelajaran dengan berdoa, 4) Guru mengucapkan salam.

b. Hasil Observasi Siswa

Pada kegiatan awal, semua siswa sudah mempersiapkan diri dengan baik dalam mengikuti proses pembelajaran, memperhatikan penjelasan guru di depan semua melakukannya, tetapi pada saat menyelesaikan LKS ada beberapa siswa tidak fokus dalam menyelesaikan LKS dan memilih melihat hasil kerja teman.

4. Refleksi

Setelah melakukan pengamatan atas tindakan pembelajaran di dalam kelas dan melakukan tes akhir, selanjutnya diadakan refleksi dari tindakan yang telah dilakukan dalam kegiatan siklus I didapat hasil refleksi, yaitu:

a. Pelaksanaan kegiatan pembelajaran yang dilakukan oleh guru belum sesuai dengan RPP yang telah disusun.

b. Guru belum sepenuhnya menjelaskan materi dengan baik.

c. Berkaitan dengan Aktivitas Siswa

d. Sebagian siswa belum dapat memahami isi cerpen .

e. Masih ada siswa yang tidak serius dalam mengikuti proses pembelajaran.

\section{c. Tes Akhir Siklus I}

Hasil tes akhir siklus I dalam pembelajaran memahami isi cerpen yang terdiri dari empat aspek yang diamati yaitu, 1) menentukan latar, 2) menetukan tokoh, 3) menentukan tema, 4) menentukan alur dalam cerita pendek. berikut hasil tes akhir siklus I dapat dilihat pada tabel berikut:

Tabel 3.2

Hasil Tes Memahami Isi Cerpen Siswa Kelas IV SD Negeri 69 Ambon Siklus I

\begin{tabular}{|c|c|c|c|c|c|c|c|}
\hline \multirow{2}{*}{ No } & \multirow{2}{*}{$\begin{array}{c}\text { Inisial } \\
\text { Siswa }\end{array}$} & $\begin{array}{c}\text { Mengamati } \\
\text { Gambar } \\
\text { Cerpen }\end{array}$ & $\begin{array}{c}\text { Menentukan } \\
\text { Tema } \\
\text { Cerpen }\end{array}$ & $\begin{array}{c}\text { Menentukan } \\
\text { Tokoh Cerpen }\end{array}$ & $\begin{array}{c}\text { Menentukan } \\
\text { Alur } \\
\text { Cerpen }\end{array}$ & \multirow{2}{*}{$\begin{array}{c}\text { Nilai } \\
\text { Akhir }\end{array}$} & Keterangan \\
\cline { 3 - 7 } & $0-20$ & $0-30$ & $0-20$ & $0-30$ & 78 & Baik \\
\hline 1 & M.R.S & 16 & 21 & 20 & 21 & 76 & Baik \\
\hline 2 & R.B.R & 15 & 21 & 20 & 20 & 76 \\
\hline
\end{tabular}




\begin{tabular}{|c|c|c|c|c|c|c|c|}
\hline 3 & A.V.W & 12 & 20 & 19 & 21 & 72 & Baik \\
\hline 4 & S.D.M & 11 & 18 & 19 & 20 & 68 & Baik \\
\hline 5 & D.R & 11 & 17 & 19 & 19 & 66 & Baik \\
\hline 6 & A.W & 12 & 17 & 18 & 17 & 64 & Cukup \\
\hline 7 & M.I.D & 10 & 13 & 18 & 17 & 58 & Cukup \\
\hline 8 & A.L & 10 & 11 & 17 & 14 & 52 & Kurang \\
\hline 9 & H.H & 11 & 10 & 17 & 12 & 50 & Kurang \\
\hline
\end{tabular}

Berdasarkan tabel 3.2 di atas dapat diketahui bahwa kemampuan siswa dalam memahami isi cerpen pada siklus I diperoleh 5 siswa atau 56\% memiliki kemampuan memahami isi cerpen dengan kategori baik dan sebanyak 2 siswa atau $22 \%$ memiliki kemampuan dalam memahami isi cerpen dalam kategori cukup dan 2 siswa atau $22 \%$ memiliki kemampuan dalam kemampuan memahami isi cerpen dalam kategori kurang. Ratarata nilai siswa dalam memahami isi cerpen adalah $64.8 \%$.

Berkaitan dengan presentase ketuntasan kemampuan siswa yang diperoleh pada siklus I, yaitu $64.8 \%$ maka peneliti dan guru menilai bahwa perolehan presentase ini masih sudah mencapai kriteria keberhasilan penelitian. Namun masih terdapat beberapa siswa yang mengalami kesulitan dalam memahami isi cerpen dengan baik dan benar. Oleh karena itu peneliti dan guru akan melanjutkan pelaksanaan tindakan perbaikan pada siklus II dengan berupaya semaksimal mungkin untuk memperbaiki kekurangan yang terdapat pada siklus I, sehingga diharapkan kemmpuan siswa dalam memahami isi cerpen dapat meningkat. Pelakasanaan pembelajaran yang akan dilakukan pada siklus II tetap berpatokan pada rencana pelaksanaan pembelajaran yang telah disusun pada siklus I sesuai penerapan model pembelajaran Word Square.

\section{d. Hasil Tes Siklus 2}

Tabel 4.3

Hasil Tes Memahami Isi Cerpen Siswa Kelas IV SD Negeri 69 Ambon Siklus II

\begin{tabular}{|c|c|c|c|c|c|c|c|}
\hline \multirow{3}{*}{ No } & \multirow{3}{*}{$\begin{array}{l}\text { Inisial } \\
\text { Siswa }\end{array}$} & \multicolumn{4}{|c|}{ Aspek Yang Dinilai } & \multirow{3}{*}{ Nilai Akhir } & \multirow{3}{*}{ Keterangan } \\
\hline & & $\begin{array}{c}\text { Mengama } \\
\text { ti Gambar } \\
\text { Cerpen }\end{array}$ & $\begin{array}{c}\text { Menentukan } \\
\text { Tema } \\
\text { Cerpen }\end{array}$ & $\begin{array}{c}\text { Menentukan } \\
\text { Tokoh } \\
\text { Cerpen }\end{array}$ & $\begin{array}{c}\text { Menentukan } \\
\text { Alur } \\
\text { Cerpen }\end{array}$ & & \\
\hline & & $0-20$ & $0-30$ & $0-20$ & $0-30$ & & \\
\hline 1 & M.R.S & 18 & 21 & 19 & 28 & 86 & Sangat Baik \\
\hline 2 & R.B.R & 15 & 21 & 19 & 30 & 85 & Sangat Baik \\
\hline 3 & A.V.W & 20 & 21 & 18 & 25 & 84 & Sangat Baik \\
\hline 4 & S.D.M & 20 & 21 & 18 & 25 & 83 & Sangat Baik \\
\hline 5 & D.R & 19 & 20 & 19 & 29 & 83 & Sangat Baik \\
\hline 6 & A.W & 19 & 21 & 19 & 29 & 82 & Sangat Baik \\
\hline 7 & M.I.D & 13 & 21 & 18 & 28 & 80 & Sangat Baik \\
\hline 8 & A.L & 15 & 15 & 20 & 28 & 78 & Baik \\
\hline 9 & H.H & 15 & 15 & 18 & 28 & 76 & Baik \\
\hline & & & Rata-rata & & & 81,90 & Tuntas \\
\hline
\end{tabular}


Berdasarkan tabel 4.3 di atas, dapat diketahui bahwa kemampuan siswa dalam memahami isi cerpen pada siklus II dapat dilihat bahwa, sebanyak 7 siswa atau $78 \%$ memiliki kemampuan memahami isi cerpen dalam kategori sangat baik. dan sebanyak 2 siswa atau $22 \%$ memiliki kemampuan memahami isi cerpen dengan kategori baik. rata-rata nilai siswa dalam memahami isi cerpen adalah $81,90 \%$.

Hasil belajar siswa dengan penggunaan model pembelajaran Word Square dapat dijelaskan brdasarkan hasil tes akhir pada siklus I dan siklus II, yaitu mengalami peningkatan kearah yang lebih baik, hal tersebut dapat dilihat pada tabel 4.3. Dari tabel-tabel tersebut, rata-rata kemampuan siswa dalam pembelajaran memahami isis cerpen meningkat, yaitu mengahsilkan presentase $100 \%$.

Dari hasil tes siklus I sebanyak 6 siswa dengan presentase $67 \%$ memperoleh nilai $\geq$ 65 dan 3 siswa dengan presentase $67 \%$ memperoleh nilai $\geq 65$. Perolehan tersebut menggambarkan pelaksanaan siklus I belum mencapai kriteria ketuntasan klasikal, yaitu $80 \%$. Selanjutnya refleki pada siklus I, menunjukan bahwa terdapat kekurangan yang terjadi pada proses pembelajaran. Dengan memperhatikan kekurangan pada siklus I, maka penelitian dilanjutkan pada siklus II. Diharpkan agar dapat menerapkan model pembelejaran Word Square dengan baik sesuai dengan langkah-langkah yang telah disusun.

Berdasrkan hasil refleksi pada siklus I, maka diputuskan penelitian dilanjutkan pada siklus II untuk memperbaiki kelemahan atau kekuranagn yang terapat pada siklus I. Dan hasil refleksi pada siklus II, menunjukan bahwa pelaksanaan tindakan pada siklus II berlangsung dengan baik. Kelemahan yang terjadi pada siklus I dapat diperbaiki dengan baik pada siklus II. Terlihat juga bahwa guru telah menggunakan langkah-langkah model pembelajaran Word Square dengan baik sesuai dengan RPP yang disusun oleh peneliti.

Dalam penggunaan model pembelajaran Word Square sudah jelas terbukti bahwa siswa lebih bersemangat dalam mengikuti pembelajaran memahami isi cerpen. Dengan penggunaan model pembelajaran Word Square dapat mengurangi kebosanan siswa. Siswa terlihat aktif sehingga proses pembelajaran berlangsung dengan baik serta kemampuan siswa dalam memahami isi cerpen dapat meningkat.

\section{KESIMPULAN}

Berdasarkan hasil dan pembahasan dalam penelitian ini maka dapat disimpulkan bahwa melalui Model Pembelajaran Word Square dapat meningkatkan kemampuan memahami isi cerpen pada siswa kelas IV SD Negeri 69 Ambon. Hal ini berdasarkan dari hasil tes setiap siklus, yaitu pada siklus I siswa memperoleh kriteria ketuntasan minimal $(\mathrm{KKM}) \geq 65$ sebanyak 5 siswa dengan presentase sebanyak $74 \%$ sedangkan pada siklus II meningkat $81,90 \%$, yaitu menjadi $100 \%$ dengan jumlah siswa yang memperoleh nilai $\geq 65$ sebanyak 9 siswa.

\section{DAFTAR PUSTAKA}

Aminuddin. 2004. Pengantar Apresiasi Karya Sastra. Bandung: Sinar Baru Algesindo.

Aqib, Zainal. 2013. Model-model, Media dan Strategi Pembelajaran Kontekstual. Bandung: Yrama Widya

Arikunto, S. 2006. Penelitian Tindakan Kelas. Jakarta: PT Bumi Aksara. Effendi, S., dan Tukiran., 2012. Metode Penelitian Survei, Jakarta: LP3ES

Gunarsa, Singgih, Y., dan Singgih, D., 1980. Psikologi Remaja, Jakarta: BPK Gunung Mulia.

Jabrohim, dkk. 2003. Cara Menulis Kreatif. Yogyakarta: Pustaka Pelajar. 
Jampar, M.S., 2017. Peningkatan Kemampuan Memahami Isi Cerita Pendek Melalui Penerapan Metode Circ Siswa Kelas V. Jakarta: UNY

Jauhari, Heri. 2013. Terampil Mengarang. Bandung: Nuansa Cendekia.

Kurniasih, Imas dan Berlin S., Ragam Pengembangan Model Pembelajaran Untuk Peningkatan Profesional Guru. Surabaya: Kata Pena. 2015.

Nurgiyantoro, B., 2012. Statistika Terapan Untuk Penilaian Ilmu-ilmu Sosial. Yogyakarta: Gadjah Mada University Press.

Priyatni, E.T., 2010. Membaca Sastra dengan Ancangan Literasi Kritis. Jakarta: Bumi Aksara

Sudarman, P., Menulis Di Media Massa. Yogyakarta: Pustaka Pelajar.

Sudijono, A., 2011. Pengantar Evaluasi Pendidikan. Jakarta: Rajawali Pers.

Sukandheni, dkk,. 2014. Pengaruh Penerapan Model Pembelajaran Word Square Berbasis Lingkungan Terhadap Hasil Belajar. Universitas Pendidikan Ganesa. Vol 2 No 1.

Sumardjo, J., 2001. Catatan Kecil Tentang Menulis Cerpen. Yogyakarta: Pustaka Pelajar

Tarigan, H.G. 1990. Menulis sebagai Suatu Keterampilan Berbahasa. Bandung: Angkasa.

Trianto, 2011. Mendesain Model Pembelajaran Inovatif-Progresif: Konsep, Landasan, dan Implementasinya pada Kurikulum Tingkat Satuan Pendidikan (KTSP). Jakarta: Kencana.

Wiriaatmadja, R., 2008. Model Penelitian Tindakan Kelas. Bandung: Remaja Rosdakarya

Wiyanto, A., 2005. Kesastraan Sekolah Penunjang Pembelajaran Bahasa Indonesia SMP dan SMA. Jakarta: Grasindo

Wiyatmi. 2009. Pengantar Kajian Sastra. Yogyakarta: Pustaka Book Publisher. 